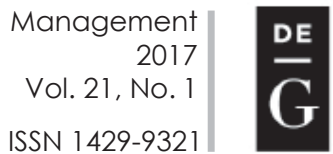

ISSN 1429-9321
DE DE GRUYTER

OPEN

DOI:

10.1515/manment-2015-0079

SYLWIA STAŃCZYK

\title{
Climate for Innovation impacts on Adaptive \\ Performance. \\ Conceptualization, Measurement, and \\ Validation
}

Sylwia Stańczyk, PhD, Assistant Professor Wroclaw University of Economics

\section{Introduction}

The construct of organizational climate was primary settled by K. Lewin, R. Lippitt and R.K. White (1939). Organizational climate in general denotes the behavior, attitudes and feelings of the organization. It influences organizational operating processes such as communications, problem solving, decision making and the way organization learns. A climate for innovation, consequently, is the perception employees embrace about innovation in the business settings (Payne, Pugh, 1976).

There are theories and approaches highlighted organizational structure, flexibility and competency of the organizations as the basis of the management and as the factors determining organizational performance. There are also approaches reflected organizational atmosphere, participative management style and motivations for being innovative as the key prerequisites for managers to effectively organize and manage organization. Organizational achievement is essentially accustomed by the organizational culture as well as climate. B. Lawson and 
Management

2017

Vol. 21, No. 1

D. Samson (2001) recognized four constituents of organizational climate: a) tolerance of ambiguity; b) empowerment of employees; c) allocation of creative time and d) knowledge sharing and communication among within the company and its network.

Innovativeness could be defined as the inclination to generate and adopt new products, new processes, and new business systems (Knowles et al. 2008). Innovativeness can be also understood as an attribute of culture that addresses the openness to new ideas. Therefore, innovativeness move organization towards being innovation oriented (Hurley, Hult 1998). As a result, climate for innovation exemplifies recognizable expression of a culture characterized by pro-innovation and it has an affirmative influence on innovation in organization (Crespell, Hansen 2008). Construct of climate for innovation, has been described as a framework consisting five important factors: team cohesion, supervisory encouragement, resources, autonomy, and openness to innovation (Nybakk, Crespell, Hansen 2011). In addition, some research advocates that one factor of accomplishing a solid climate for innovation is manager behavior (Schein, 2011). Climate for innovation may influence improved organizational results and in consequence it may provide change of patterns of interaction (Feldman, Pentland 2003) and successively lead to adaptive behavior and performance.

As enablers, all of the climate dimensions are hypothesized to have a joint direct effect on the adaptive performance.

Numerous researchers have acknowledged an affirmative relationship between a climate for innovation and organizational achievements (e.g. Deshpandé, Farley 2004). Climate has a tendency to support adaptive performance of an individuals and teams since it forms supportive organizational setting. Nevertheless not much research has been done on climate for innovation (Sarros et al. 2008) as a factor influencing adaptive performance (Magee 2002). As such, adaptive performance as well as organizational performance is supposed to be determined by the climate for innovation. Therefore, it is proposed here to examine the subsequent hypothesis: Climate for innovation affects adaptive performance positively. Within the individual adaptive performance, the research comprises four dimensions borrowed from E.D. Pulakos' et al. (2000): solving problems creatively, dealing with uncertain or unpredictable work situations, learning new tasks, technologies and procedures, and handling work stress.

The objective of the paper is to identify and reflect climate for innovation as construct that influences individual adaptive performance. To do so, it is a necessity to develop and assess valid research instrument. Consequently, the

41

SYLWIA STAŃCZYK 


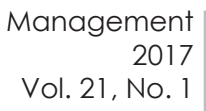

article reviews some aspects concerning the adaptation of existing instruments and measurements. On that basis, the aims of this research are threefold: (1) to find and adapt an instrument to a research context in order to measure Climate for Innovation (CI) and Individual Adaptive Performance (AP), (2) to develop the appropriate research instrument to study those two constructs, and finally (3) to test the adapted research instrument from the perspective of its validity and reliability.

\section{Method}

\section{Sample and procedure}

The data for this research were collected from a random group of managers. All measures have been borrowed from existing studies and adapted to Polish settings.

Data were gathered from respondents worked at different enterprises located in Poland. The study population comprised a list of enterprises from the voivodship of Lower Silesia in Poland. The sample met the following criteria: firm had commercial recognition, firm should operate as a private business. This process allowed selecting 387 firms as a research population from a variety of industries, including manufacturing, technology, financial services, wholesale, retail, and insurance. The structure of the researched group was related with The Central Statistical Office (keeping the National Official Business Register) and was found as a reasonable representation of participating managers in the research population.

The sample used for the study consisted of 387 respondents which are result of convenient sample. This sampling method has been conducted based on whether contact details of target respondents can be obtained. A survey has been done using an email and paper questionnaire. An overall response rate yielded 78\% (301 were returned) due to a number of requests to the participants. The response rate is an above average for studies where managers are sample group (Cycyota, Harrison 2006; Baruch 2008). Incomplete data has been eliminated giving 280 valid questionnaires to accept and take into consideration for further evaluation ( $93 \%$ of returned questionnaires and $72 \%$ of all questionnaires that were sent out).

The average age of participating respondents was 25-35 years old (SD $=0.8)$. Of the respondents, $10 \%$ was top-level managers, $25 \%$ executives, and $55 \%$ uppermiddle managers. The participant respondents mostly worked in organizations with 51-250 employees. 


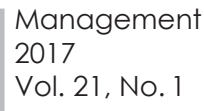

A non-response bias test was accompanied using the pattern recommended by Armstrong and Overton (1977), and applied by others (by Burkam and Lee's (1998), and by Lindner, Murphy, Briers (2001)). A $t$-test has been used to compare differences in $\mathrm{CI}$ and $\mathrm{AP}$ given by early and late respondents. Due to this test no inconsistencies were found ( $p>.05)$, suggesting no non-response bias.

\section{Measures}

We searched for scales for researching $\mathrm{CI}$ and AP constructs in existing research. The items used in this study and included in the questionnaire were borrowed from valid scales and as a result measures used have been adjusted from the prior research in the writings. As a first step it was essential to found the constructs' validity of those included in the research. Evaluating the measurement scheme was the second step. This allows ensuring that all items and corresponding dimensions were loading significantly on at least one factor as estimated from prior studies adopting the same scales. .

The measurement model consisted of two constructs: CI, and AP. The complete set of items used in this research, as well as factor loadings, average variance extracted (AVE), and internal consistency reliability, are presented in table 1.

Due to the result of the factor analysis, eight of the dimensions for CI were excluded, (the factor loadings under .50) and 12 factors were included in the theoretical configuration. For AP all items represent clear results. All items have been correctly loaded on their corresponding factors, with no cross-loadings above 0.3 . All constructs showed appropriate reliability and validity.

\section{Climate for Innovation Scale}

The CI scale proposed by Amabile et al. (1996) has been used to study the five CI dimensions: (a) team cohesion (4 items), (b) supervisory encouragement (4 items), (c) resources (4 items), (d) autonomy (4 items), and (e) openness to innovation (4 items). The CI Scale has been shown in previous studies as indicated and has internal consistency reliability on the acceptable level (all Cronbach's alpha coefficients $>$.70). The internal consistency reliability evidences construct and content validity (Podsakoff et al. 1990).

The dimension of the CI in this research was based on Amabile et al.' (1996) measurement instrument, but, following argumentation of Nybakk, Crespell and Hansen (2011) composite indicators have been used in which four items per climate dimension were united. Each of the 20 items has been assessed applying a scale ranging from 1 (strongly disagree) to 7 (strongly agree).

43 
Table 1. Cl. Average value for a 20 -Item scale. Single-Item Analysis

- Innovation is rewarded

\section{3,28}

- It is often difficult to carry out organizational changes

- New ideas are generally resisted

- People are encouraged to take risks even if it results in failure

- People do not have a say in the way their job is performed

- Employees determine their own work

- Employees have the freedom to decide how they are going to do their work

- People feel like they do not have control over their own work

- People have too much work to accomplish in the allotted time

- It is difficult for people to get the resources they need to do their work

- Generally, people can get the resources they need for their work

- If people need information to do their work, it is readily accessible within the organization

- Supervisors support their teams within the organization

- People feel that top management is enthusiastic and confident about their work

- People do not feel encouraged by their superiors to do creative work

- People ignore what their superiors expect for them

- Employees lack a shared vision of where we are going and what we are trying to do

- Communication is free and open within teams

- People feel they cannot trust their coworkers

- Teams are committed to their work

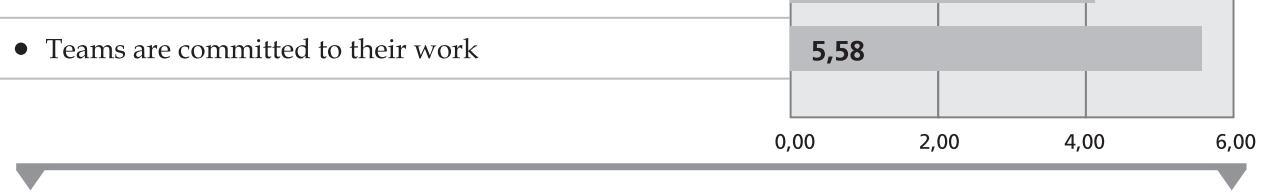

Source: own study

\section{4,16}

\section{3,65}

3,57

5,36

5,36

4,84

3,03

3,68

2,70

5,19

4,42

4,15

4,36

3,36

2,43

2,62

4,87

4,11 
CI scale was reduced as a result of first step in the factorial analysis process. We examined scale reliability (alfa) to guarantee a value equal or above 0.70 . A factor loading analysis of these twenty items produced twelve items. Factor loadings of the item included in the analysis ranged from .55 to 0.84. Finally, Cronbach's alpha coefficients in this research oscillated from .5 (Openness for Innovation) to .75 (Supervisory encouragement and Autonomy). This is a good base to consider it as acceptable assuming the comparatively small number of items in each subscale. But then also Cronbach's alpha for Team cohesion subscale was .57. Thus, we sought to take carefully the results concerning those two dimensions and as a result we decided to use $\mathrm{CI}$ as an unidimensional one. Concerning the reliability for $\mathrm{CI}$ scale, Cronbach's alpha value $(\mathrm{N}=280)$ was .73 at the individual level. This value varies downward when each item of the instrument is drawn. We also tested convergent reliability (CR)as supportive to average variance values (AVE). AVE is above .5 for all items. The AVE of the total scale is .75 and $C R$ is .94 suggesting postulated criteria have been met.

Table 2. AP. Average value for an 8-Item scale. Single-Item Analysis

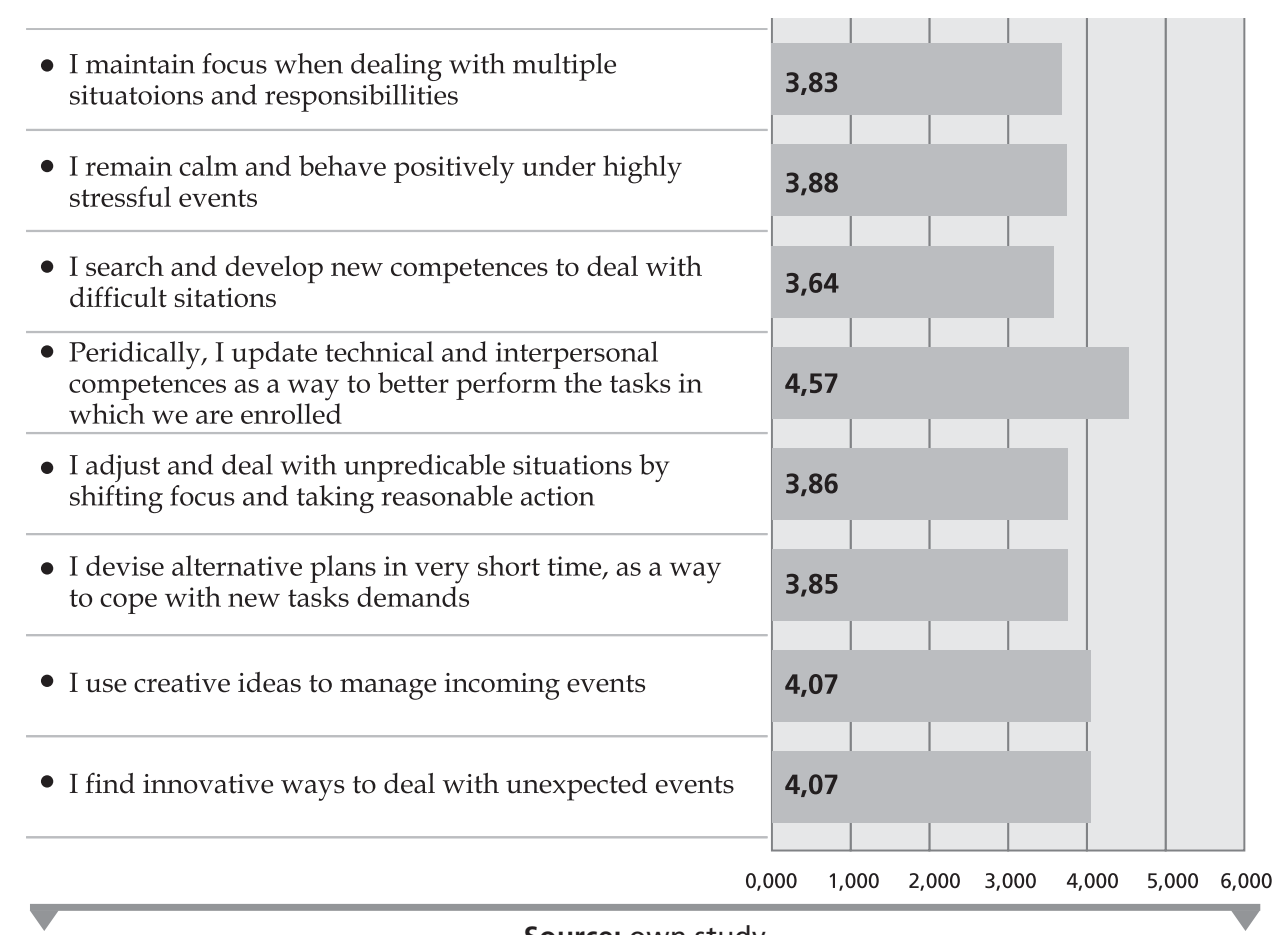

Source: own study

45

SYLWIA STAŃCZYK 


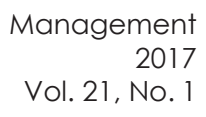

Totally, the number of factors incorporated in the analysis was 20. Of the 20 items visually analyzed, average score value is 4 and higher for 11 items (table 1). For 2 of items, average value of answers is below 3.

The final list of CI items, as pointed earlier, contained 12 items, divided into five sub-scales. The remaining 8 items represent 5 primary dimensions (table 6).

The descriptive analysis of the CI construct shows average values (Mean) for each one of the items and range a value from 2.43 to 5.58 ( $\mathrm{SD}=1.22-1.77)$. We noticed that one of the 20 items obtained a median of six. It relates to the mark associated to the extremely positive answer, nevertheless the scores interims also grasped lower scores, that is, the score two (table 3). The mode value that appears most often in a set of data is 5 (7 items).

AP Scale: This scale was built upon E.D. Pulakos' et al. (2000) eightdimensional model of AP and we decided only to consider those dimensions that were reported by E.D. Pulakos et al. (2000). Consequently, this scale was used to examine the four AP factors of (a) solving problems creatively (2 items), (b) dealing with uncertain or unpredictable work situations ( 2 items), (c) learning new tasks, technologies and procedures (2 items), and (d) handling work stress ( 2 items). Each of the 8 items was evaluated using a scale from 1 (strongly disagree) to 7 (strongly agree). The measurement of the AP in this research was based on adaptation of E.D. Pulakos et al. (2000) scale, however composite indicators were used which is counted as the the combination of two items per AP.

AP scale has demonstrated the reliability as well as the discriminant and convergent validity of the subscale in the aforementioned research (Pulakos et.al. 2000; Marques-Quinteiro et.al 2015). Table 6 reports results of factor analysis. The Cronbach's alpha coefficient representing the quality of the scale was .84 and .86 respectively. In this study's sample factor loadings of the item ranged from .56 to .83 and the Cronbach's alpha coefficient of the quality of scale items is .84 . Cronbach's alpha value concerning the reliability for each subscale scale at the individual level $(N=280)$ was $.53-.86$. To support convergent validity average variance values (AVE) has been assessed and it is above .5 for this construct. The AVE of the total scale is .81 and CR is .84 meeting postulated criteria.

As a result of factor analysis, validity and reliability analysis all of 8 items grouped into 4 dimensions were included in the analysis of the data.

The descriptive analysis of the AP construct demonstrates an average values (Mean) for each items around a value of $4(\mathrm{SD}=1.2-1.46)$. All of the 8 items presented a median of four (table 4). The mode value that appears most often in a set of data is 3 ( 3 items) and 4 (5 items).

Climate for Innovation impacts on Adaptive Performance. Conceptualization, Measurement, and Validation 
Tables 1 and table 2 shows the average value of responses in the form of bar charts concerning research items. Descriptive statistics such as means, median, standard deviations, and modal among the variables are included in table 3 and 4 . Table 6 demonstrates factor analysis results, as well as average variance extracted, composite reliability and alfa.

Table 3. Cl - Items and descriptive characteristics

\begin{tabular}{|c|c|c|c|c|}
\hline Dimensions/Items & Mean & Me & SD & Mo \\
\hline \multicolumn{5}{|c|}{ Team cohesion } \\
\hline Teams are committed to their work & 5.58 & 6 & 1.22 & 5 \\
\hline People feel they cannot trust their coworkers & 4.11 & 4 & 1.77 & 5 \\
\hline Communication is free and open within teams & 4.87 & 5 & 1.45 & 5 \\
\hline $\begin{array}{l}\text { Employees lack a shared vision of where we are going } \\
\text { and what we are trying to do }\end{array}$ & 2.62 & 2 & 1.52 & 1 \\
\hline \multicolumn{5}{|c|}{ Supervisory encouragement } \\
\hline People ignore what their superiors expect from them & 2.43 & 2 & 1.62 & 1 \\
\hline $\begin{array}{l}\text { People do not feel encouraged by their superiors to do } \\
\text { creative work }\end{array}$ & 3.36 & 3 & 1.77 & 2 \\
\hline $\begin{array}{l}\text { People feel that top management is enthusiastic and } \\
\text { confident about their work }\end{array}$ & 4.36 & 4 & 1.77 & 4 \\
\hline $\begin{array}{l}\text { Supervisors support their teams within the } \\
\text { organization }\end{array}$ & 4.15 & 4 & 1.77 & 5 \\
\hline \multicolumn{5}{|l|}{ Resources } \\
\hline $\begin{array}{l}\text { If people need information to do their work, it is } \\
\text { readily accessible within the organization }\end{array}$ & 4.42 & 5 & 1.36 & 5 \\
\hline $\begin{array}{l}\text { Generally, people can get the resources they need for } \\
\text { their work }\end{array}$ & 5.19 & 5 & 1.25 & 5 \\
\hline $\begin{array}{l}\text { It is difficult for people to get the resources they need } \\
\text { to do their work }\end{array}$ & 2.70 & 2 & 1.53 & 2 \\
\hline $\begin{array}{l}\text { People have too much work to accomplish in the } \\
\text { allotted time }\end{array}$ & 3.68 & 4 & 1.44 & 4 \\
\hline
\end{tabular}

47 


\begin{tabular}{|c|c|c|c|c|}
\hline \multicolumn{5}{|l|}{ Autonomy } \\
\hline $\begin{array}{l}\text { People feel like they do not have control over their } \\
\text { own work }\end{array}$ & 3.03 & 3 & 1.48 & 2 \\
\hline $\begin{array}{l}\text { Employees have the freedom to decide how they are } \\
\text { going to do their work }\end{array}$ & 4.84 & 5 & 1.45 & 5 \\
\hline Employees determine their own work & 5.36 & 5 & 1.39 & 6 \\
\hline $\begin{array}{l}\text { People do not have a say in the way their job is } \\
\text { performed }\end{array}$ & 5.36 & 2 & 1.38 & 1 \\
\hline \multicolumn{5}{|c|}{ Openess to innovation } \\
\hline $\begin{array}{l}\text { People are encouraged to take risks even if it results in } \\
\text { failure }\end{array}$ & 3.57 & 4 & 1.40 & 4 \\
\hline New ideas are generally resisted & 3.65 & 4 & 1.52 & 4 \\
\hline It is often difficult to carry out organizational changes & 4.16 & 4 & 1.22 & 4 \\
\hline Innovation is rewarded & 3.28 & 3 & 1.65 & 3 \\
\hline
\end{tabular}

Source: own study

Table 4. AP - Items and descriptive characteristics

\begin{tabular}{|c|c|c|c|c|}
\hline Dimensions/Items & Mean & Me & SD & Mo \\
\hline \multicolumn{5}{|c|}{ Solving problems creatively } \\
\hline I find innovative ways to deal with unexpected events & 4.07 & 4 & 1.20 & 4 \\
\hline I use creative ideas to manage incoming events & 4.07 & 4 & 1.27 & 4 \\
\hline \multicolumn{5}{|c|}{ Dealing with uncertain and unpredictable work situation } \\
\hline $\begin{array}{l}\text { I devise alternative plans in very short time, as a way } \\
\text { to cope with new task demands }\end{array}$ & 3.85 & 4 & 1.39 & 3 \\
\hline $\begin{array}{l}\text { I adjust and deal with unpredictable situations by } \\
\text { shifting focus and taking reasonable action }\end{array}$ & 3.86 & 4 & 1.35 & 3 \\
\hline \multicolumn{5}{|c|}{ Learning work tasks, technologies and procedures } \\
\hline $\begin{array}{l}\text { Periodically, I update technical and interpersonal } \\
\text { competences as a way to better perform the tasks in } \\
\text { which we are enrolled }\end{array}$ & 4.57 & 4 & 1.10 & 4 \\
\hline
\end{tabular}


Management

2017

Vol. 21, No. 1

\begin{tabular}{l|l|l|l|l}
$\begin{array}{l}\text { I search and develop new competences to deal with } \\
\text { difficult situations }\end{array}$ & 3.84 & 4 & 1.44 & 3 \\
\hline \multicolumn{5}{c}{ Handling work stress } \\
$\begin{array}{l}\text { I remain calm and behave positively under highly } \\
\text { stressful events }\end{array}$ & 3.88 & 4 & 1.46 & 4 \\
\hline $\begin{array}{l}\text { I maintain focus when dealing with multiple } \\
\text { situations and responsibilities }\end{array}$ & 3.83 & 4 & 1.42 & 4 \\
\hline
\end{tabular}

\section{Measurement}

To construct proper tool for measurement in the research, we have adapted the typical procedures. To clean the preliminary quota and to confirm consistency of the measurement, and scales validity and reliability we followed appropriate steps. The results of procedure used for each suggested measurement scale number of items were rejected from the analysis.

The measurement approach has been assessed by evaluating statistics regarding reliability and validity. Cronbach's alpha values have been included as well as CR, factor loadings (FL), and AVE. The average variance extracted (AVE) has been applied to assess the convergent validity of the scales. AVE for each construct, i.e. CI and AP of .50 has been obtained and therefore it exceeds the suggested minimum cut - off value Table 6 presents all of the AVE values.

According to the standards, the reliability level is suggested to be satisfactory if the value is at least .8 for the basic research and .7 for the exploratory one (Nunnally 1978). The instrument reliability has been calculated through the internal consistency of the items has been also confirmed by Cronbach's alpha, indicating proper acceptable scores, i.e. .73 and .84. It is worth remarking that high values of alpha are usually noticed in scales with many items. It is due to the point the alpha is contingent on the number of items in the scale. This same regularity is observed with instruments with few items. In our case the AP construct meets this regularity. In our research, an alpha value oscillates around .50 according to one dimension of $\mathrm{CI}$ and one dimension of AP which can be interpreted as construct is acceptable. For all multi-item constructs included in the research Cronbach's alphas were tolerable and are presented in table 5. We adopted the level of significance in this study of .05 . The above shared outcomes establish the convergent validity of adapted measures.

49

SYLWIA STAŃCZYK 
Table 5. Measurement of latent constructs

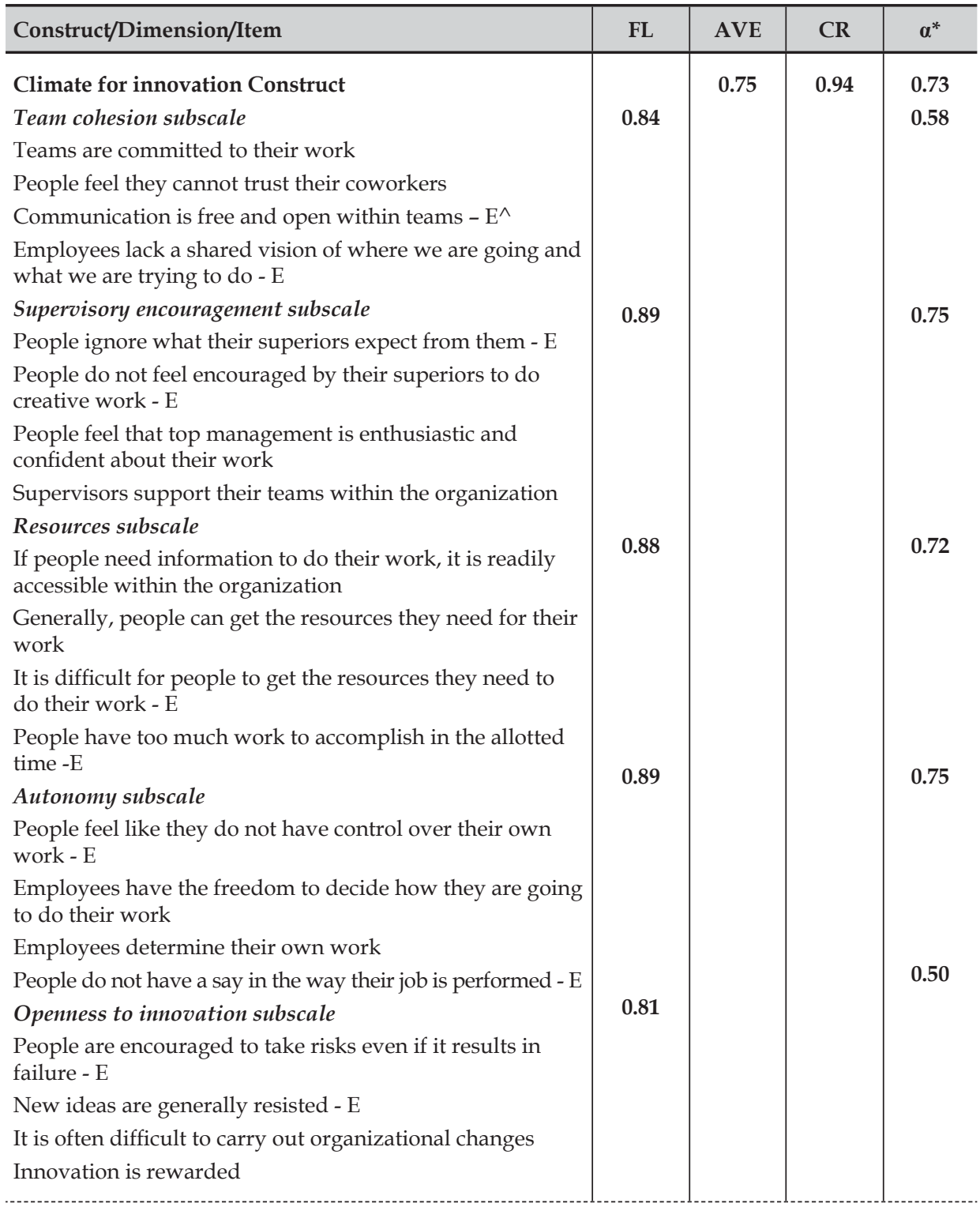


Management

2017

Vol. 21, No. 1

Adaptive performance Construct

Solving problems creatively

I find innovative ways to deal with unexpected events

I use creative ideas to manage incoming events

Dealing with uncertain and unpredictable work situation

I devise alternative plans in very short time, as a way to cope with new task demands

I adjust and deal with unpredictable situations by shifting focus and taking reasonable action

Learning work tasks, technologies and procedures

Periodically, I update technical and interpersonal

competences as a way to better perform the tasks in which we are enrolled

I search and develop new competences to deal with difficult situations

Handling work stress

I remain calm and behave positively under highly stressful events

I maintain focus when dealing with multiple situations and responsibilities

\begin{tabular}{|l|l|l|l}
0.94 & & 0.81 & 0.84 \\
0.83 & & & 0.86 \\
0.91 & & & 0.53 \\
0.92 & & & 0.81 \\
& & & \\
& & & \\
& & & \\
& & & \\
\end{tabular}

Note that composite reliability is an indicator of reliability similar to Cronbach's Alpha.

*when items were excluded; $\wedge$ item excluded

Source: own study

\section{Results. Analysis and findings}

Table 6 reports the correlation matrix among the measures. As shown, each dimension met the criterion. Inter-correlation analysis showed significant relationships between many dimensions. Some of the measures demonstrate inherent overlap. The highest correlation among the CI variables being $>.5$ exists between Supervisory encouragement, Resources, and Autonomy. Four dimensions of AP are weakly correlated with each other.

The simple regression analysis was used to examine hypothesized relationship to describe the directed dependencies among variables (table 6). We were used exploratory data analysis, an ANOVA, to indicate the variance of each component of the each set of terms of a linear model. This concerns relationships between CI and AP. As expected, results revealed that $\mathrm{CI}$ influences AP. The outcomes of the regression analysis are presented in the table 7.

51 
Table 6. Intercorrelations Matrix of $\mathrm{Cl}$ and AP dimensions

\begin{tabular}{|c|c|c|c|c|c|c|c|c|c|}
\hline & \multicolumn{9}{|c|}{ Correlation } \\
\hline & 1 & 2 & 3 & 4 & 5 & 6 & 7 & 8 & 9 \\
\hline 1. Team cohesion & 1 & & & & & & & & \\
\hline 2. Supervisory encouragement & 0.54 & 1.00 & & & & & & & \\
\hline 3. Resources & 0.57 & 0.67 & 1.00 & & & & & & \\
\hline 4. Autonomy & 0.40 & 0.51 & 0.52 & 1.00 & & & & & \\
\hline 5. Openness to innovation & -0.28 & -0.33 & -0.30 & -0.24 & 1.00 & & & & \\
\hline 6. Solving problems creatively & 0.21 & 0.42 & 0.32 & 0.30 & -0.32 & 1.00 & & & \\
\hline $\begin{array}{l}\text { 7. Dealing with uncertain and } \\
\text { unpredictable work situations }\end{array}$ & 0.13 & 0.31 & 0.19 & 0.18 & -0.29 & 0.64 & 1.00 & & \\
\hline $\begin{array}{l}\text { 8. Learning work tasks, } \\
\text { technologies and procedures }\end{array}$ & 0.18 & 0.37 & 0.23 & 0.14 & -0.41 & 0.49 & 0.54 & 1.00 & \\
\hline 9. Handling work stress & 0.04 & 0.26 & 0.18 & 0.20 & -0.13 & 0.33 & 0.42 & 0.34 & 1.00 \\
\hline
\end{tabular}

Source: own study

Table 7. Regression analysis

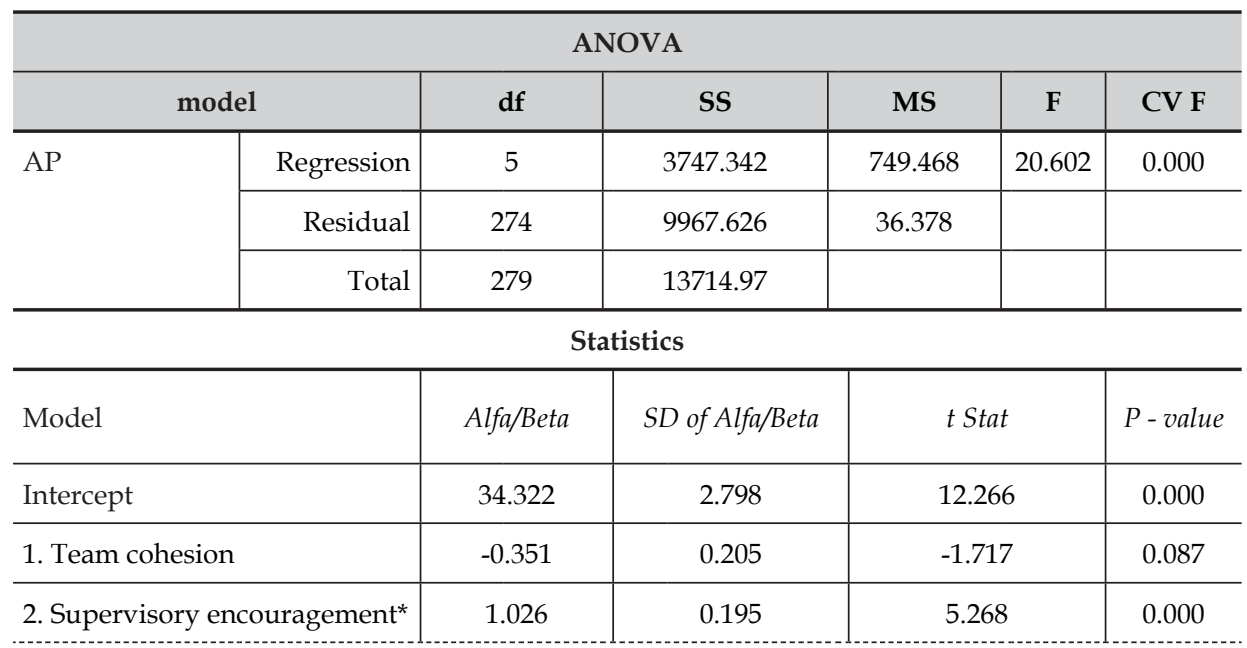


Management

2017

Vol. 21 , No. 1

\begin{tabular}{|c|c|c|c|c|c|c|c|}
\hline \multicolumn{2}{|l|}{ 3. Resources } & \multicolumn{2}{|c|}{-0.001} & 0.232 & \multicolumn{2}{|c|}{-0.004} & 0.997 \\
\hline \multicolumn{2}{|l|}{ 4. Autonomy } & \multicolumn{2}{|c|}{0.114} & 0.173 & \multicolumn{2}{|c|}{0.660} & 0.510 \\
\hline \multicolumn{2}{|c|}{ 5. Openness to innovation } & \multicolumn{2}{|c|}{-0.860} & 0.173 & \multicolumn{2}{|c|}{-4.983} & 0.000 \\
\hline \multicolumn{8}{|c|}{ Regression statistics } \\
\hline \multirow[t]{2}{*}{ Model } & $R$ & $\begin{array}{l}R \text { squ- } \\
\text { ared }\end{array}$ & $\begin{array}{l}\text { Adjusted } R \\
\text { square }\end{array}$ & $S D$ & DW Stat & VIF & $\begin{array}{l}\text { Cohen's } \\
\text { fsquare }\end{array}$ \\
\hline & 0.523 & 0.273 & 0.259 & 6.031 & 1.876 & 1.376 & 0.376 \\
\hline
\end{tabular}

*variable is significant, should be included in the model

Note: SD -standard error of the regression; df - degrees of freedom; SS -sum of squares; MS - mean squared error; F - F stat/test; CV F - critical value of F stat; DW Stat - Durbin Watson stat; VIF - variance inflation factor; Alfa/Beta - coefficients.

Source: own study

The overall fit of the model has been measured by the level of variance explained ( $\mathrm{R}$ square) by construct. The structural path significance has been recognized by a $B$ coefficient and its resultant $t$-statistic $(\mathrm{P}$ - value) and effect size (f square). The R square score of the AP construct was acceptable (.273). The B values, P-value for CI are -.351, .087 for Team cohesion; 1.026, .000 for Supervisory Encouragement; -.001, .997 for Resources, .114, .510 for Autonomy, and -.860, .000 for Openness to innovation.

The model was estimated using SPSS software. The variance inflation factor for the model (the value is 1.376) is below the acceptable threshold value of 10, demonstrating not significant multicollinearity since just one predictor is comprised in the model. The test results are presented in table 8. An output shows the results of putting a linear model to describe the relationship between $\mathrm{CI}$ and AP. The equation of the fitted/optimal model is:

$Y^{\wedge}=34,322+X^{*} 1,026$, where: $Y^{\wedge}=A P ; X=$ Supervisory encouragement

This model predicts the value of target variable based on given predictor i.e. dimensions of CI. Regression analysis shows that only one dimension of $\mathrm{CI}$ is significant and should be included in the model.

Hypothesized relationship indicates that the increase in quality of $\mathrm{CI}$ is positively associated with the AP. In general, in line with our theorizing, our results indicate that $\mathrm{CI}$ has important implications for AP. Unexpectedly; the only

53 




one variable should be included in the model, i.e. Supervisory encouragement. Thus, the relationship suggesting a positive link between CI and AP was supported for Supervisory encouragement, but not for team cohesion, resources, autonomy, and openness to innovation. As it is suggested by E.H. Schein (2011) that one way of attaining a robust $\mathrm{CI}$ is through managers behavior is supported by this study. Adjusted R square for Supervisory Encouragement was 0.259 and supports assumed relationship concerning positive relation between CI (Supervisory Encouragement) and AP. It expresses that 25.6\% of the variation of Y-values around the mean are explained by the X-values. In other words, $25.6 \%$ of the values fit the model.

\section{Conclusions and final considerations}

This research was exploratory in nature. This study set out to answer the research question if and how CI may alter AP. The outcomes of this research point out that dimensions of $\mathrm{CI}$ construct ought to associate with the AP construct in different way.

This study adapted the existing dimension of $\mathrm{CI}$ and AP and tested its content and construct validity and reliability. Respondents who take part in the research were principally managers. The high response rate has been obtained due to the quite small number of items in each construct. Probably of that reason, i.e. a small number of items the content validity increased. Because the tool was implemented to measure item by factors constructs validity was assessed in parallel to factor analysis. This kind of research, i.e. using a questionnaire provides some difficulties to assess whether participating respondents are articulating the way they really act or think. This provides desirability bias however it is a well-known issue. The desirability bias seems to be a limitation of the research presented here. Another limitation of the presented research results is that the reliability of the questionnaire should be tested again. With the exceptions of these limitations, the questionnaire is characterized by satisfactory content validity and acceptable reliability. Thus, it is suggested it can be applied to measure constructs of CI and AP association.

The items constituting the AP have been reflected appropriate for the content validity evaluation of the adjusted measurement. The CI construct was reduced in order to meet criteria of validity. The evaluation of the constructs validity of the instrument produced 12-items and 8 items for each construct correspondingly. The Cronbach's alpha was .73 and .84, and it is a value that can be perceived

Climate for Innovation impacts on Adaptive Performance. Conceptualization, Measurement, and Validation 


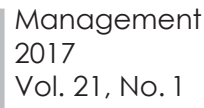

as applicable. This value was obtained by the exclusion of some items, which upraised the alpha value to .73 for $\mathrm{CI}$ construct.

The results of the present research specify that, in general, the adaptation, of the questionnaire were reasonably positive. For the future research we suggest additional research with respondents with differentiated business features.

\section{Summary}

Climate for Innovation impacts on Adaptive Performance. Conceptualization, Measurement, and Validation

The main objective of this paper was to examine the relationship between organizational climate for innovation and adaptive performance. The study was carried out in business organisations in Poland $(\mathrm{N}=387)$, representing variety of industries. The Cimate for Innovation measure and Individual Adaptive Performance measure was adopted from previous studies. The results of presented research point out that certain measurements of the organizational climate for innovation are interrelated to adaptive performance, especially supervisory encouragement. The present study discusses some aspects concerning the adaptation of existing instruments and measurements. On the basis of the research presented we indicate that, in general, the adaptation, of the mesearuments were relatively effective. The questionnaire was assessed as to be valid in terms of content for the reseraching $\mathrm{CI}$ and $\mathrm{AP}$ aspects in Poland.

Keywords: climate for innovation, adaptive performance, instrument validation.

Streszczenie

Wpływ klimatu sprzyjającego innowacjom na adaptacyjność indywidualną. Konceptualizacja, pomiar i walidacja

Celem artykułu jest przestudiowanie relacji między organizacyjnym klimatem sprzyjającym innowacyjności a indy widualną adaptacyjnością. Badania zostały przeprowadzone w organizacjach biznesowych w Polsce $(\mathrm{N}=387)$ reprezentujących różne sektory. Narzędzia pomiaru klimatu sprzyjającego innowacyjności oraz pomiaru indywidualnej adaptacyjności zostały zaadoptowane z wcześniejszych badań. Wyniki wskazują, że pewne wymiary klimatu sprzyjającego innowacyjności są

55

SYLWIA STAŃCZYK 
powiązane $\mathrm{z}$ indywidualną adaptacyjnością, szczególnie jest to wsparcie ze strony przełożonych. Przedstawione rozpoznanie poddaje także dyskusji wybrane aspekty dotyczace adoptowania istniejącego narzędzia badawczego oraz pomiaru. W świetle zaprezentowanych wyników badań można stwierdzić, że tlumaczenie, adaptacja i dalsze wykorzystanie kwestionariusza zakończyło się relatywnym sukcesem badawczym. Kwestionariusz okazał się zwalidowany $\mathrm{w}$ kategoriach treści $\mathrm{w}$ celu dokonania pomiarów w badaniach prowadzonych w Polsce.

\section{Słowa}

kluczowe: Klimat sprzyjający innowacjom, adaptacyjność indywidualna, walidacja narzędzia badawczego.

\section{Acknowledgement:}

The research is finance by the National Science Centre in Poland (grant number: DEC-2013/11/B/HS4/00647).

\section{References}

1. Amabile, T. M., Conti, R., Coon, H., Lazenby, J., Herron, M. (1996)., Assessing the work environment for creativity, "Academy of Management Journal", Vol. 39, pp. 1154-1184.

2. Armstrong, J.S.,Overton, T. (1977)., Estimating Nonresponse Bias in Mail Surveys, "Journal of Marketing Research" Vol. 14, Iss. 3, pp. 396-402.

3. Baruch Y., Holtom B. C., Survey response rate levels and trends in organizational research, Human Relations 2008, Vol. 61 (8), pp. 11391160, DOI: $10.1177 / 0018726708094863$.

4. Burkam, D. T., Lee, V. E. (1998)., Effects of Monotone and Nonmonotone Attrition on Parameter Estimates in Regression Models with Educational Data: Demographic Effects on Achievement, Aspirations, and Attitudes, "Journal of Human Resources" Vol. 33, pp. 555-575.

5. Crespell, P., Hansen, E. (2008)., Work climate, innovativeness, and firm performance in the US forest sector: in search of a conceptual framework, "Canadian Journal of Forest Research" Vol. 38, Iss. 7, pp. 1703-1715.

6. Cycyota Cynthia S. and Harrison David A., What (Not) to Expect When Surveying Executives: A Meta-Analysis of Top Manager Response Rates and Techniques Over Time, Organizational Research Methods April 2006 9, pp. 133-160, DOI:10.1177/1094428105280770.

7. Deshpandé, R., Farley, J.U. (2004)., Organizational culture, market orientation, innovativeness, and firm performance: an international research odyssey, "International Journal of Research in Marketing", Vol. 21, Iss. 1, pp. 3-22. 
8. Feldman, M. S., Pentland, B.T. (2003)., Reconceptualizing organizational routines as a source of flexibility and change, "Administrative Science Quarterly" Vol. 48, pp. 94-118.

9. Hurley, R.F., Hult, G.T. (1998)., Innovation, market orientation and organizational learning: an integration and empirical examination, "Journal of Marketing" Vol. 62, Iss. 3, pp. 42-54.

10. Lawson, B. Samson, D. (2001)., Developing Innovation Capability in Organisations: A Dynamic Capabilities Approach, "International Journal of Innovation Management" Vol. 5, Iss. 3, pp. 377-400.

11. Lewin, K., Lippitt, R., White, R. K. (1939)., Patterns of aggressive behavior in experimentally created "social climates", "Journal of Social Psychology" Vol. 10, pp. 271-299.

12. Lindner, J. R., Murphy, T. H., Briers, G. E. (2001)., Handling nonresponse in social science research, "Journal of Agricultural Education", pp. 43-53.

13. Magee, K. C. (2002)., The impact of organizational culture on the implementation of performance management, Doctoral dissertation.

14. Marques-Quinteiro, P., Ramos-Villagrasa, P.J., Passos, A.M., Curral, L. (2015)., Measuring adaptive performance in individuals and teams, "Team Performance Management" Vol. 21, Iss. 7/8, pp. 339-360, DOI: 10.1108/ TPM-03-2015-0014.

15. Nunnally, J. C. (1978)., Psychometric theory, 2nd ed. New York: McGrawHill.

16. Nybakk, E., Crespell, P., Hansen, E. (2011)., Climate for innovation and innovation strategy as drivers for success in the wood industry: moderation effects of firm size, industry sector, and country of operation, "Silva Fennica" Vol. 45, Iss. 3, pp. 415-430.

17. Payne, R. L., Pugh, D. D. (1976)., Organizational structure and climate, In: M. Dunnette (Ed.), Handbook of Industrial and Organizational Psychology (pp. 1125-1172). Chicago: Rand McNally.

18. Podsakoff, P. M., MacKenzie, S. B., Moorman R. H., Fetter, R. (1990)., Transformational leader behaviors and their effects on followers' trust in leader, satisfaction, and organizational citizenship behaviors, "The Leadership Quarterly" Vol. 1, Iss. 2, pp. 107-142, DOI:10.1016/1048-9843(90)90009-7.

19. Pulakos, E. D., Arad, S., Donovan, M.A., Plamondon, K.E. (2000)., Adaptability in the workplace: Development of a taxonomy of adaptive performance, "Journal of Applied Psychology" Vol. 85, Iss. 4, pp. 612-624, DOI: 10.1037/0021-9010.85.4.612.

20. Sarros, J. C., Cooper B. K., Santora, J. C. (2008)., Building a Climate for Innovation Through Transformational Leadership and Organizational Culture, "Journal of Leadership \&Organizational Studies", Vol. 15, Iss. 2, pp. 145158, DOI:10.1177/1548051808324100.

21. Schein, E. H. (2011)., Leadership and organizational culture, New York, Wiley.

51

SYLWIA STAŃCZYK 